\title{
Shortcommings of Ensuring Separate Human Rights Legal Regulation in Lithuania while Implementing an Aspiration of the State under the Rule of Law
}

\author{
BY LiNA BELIŪNIENE**
}

\begin{abstract}
This article deals with insights into the analysis of shortcommings of ensuring separate human rights legal regulation in Lithuania while implementing the rule of law. The shortcomings of the Lithuania legislature are highlighted in particular the failure to ensure or inappropriate or insufficient guaranteeing of separate rights. This article has chosen to present herea selection of rights from a wider range of rights to be analysed. This choice reflects not a few but a set of the most striking examples of the shortcomings of the legislature of Lithuania. These examples could be named 'the most striking' because the constitutional requirements of the legislature is to ensure that human rights are explained accurately in the wide constitutional jurisprudence, despite this fact they are not sufficiently obeyed. In this article the problem of ensuring two quite different kinds of rights are identified and analysed.These include two civil rights (i.e. the right to freedom from torture and cruel, inhuman or degradating treatment or punishment in the context of conditions of imprisonment, the right to freedom of expression and information) and one economic right - the right to freedom of individual economic activity and initiative. They distinctly approve at least a few shortcomings of legal regulation: non-complexity/non-systematicity, inconsistency, intricacy, uncertainty, and often - instability, unconstitutionality, and in some cases nonconformity with international standards of human rights protection, as well as the inaccessibility of legal regulation. In this article the recommendations of how to improve those shortcommings are considered. In light of the inability to actually fully ensured constitutional guarantees of separate human rights it could be argued that the principle of rule of law which is enshrined in the preamble of the Constitution of the Republic of Lithuania which is an aspiration, remains a major challenge for the Lithuanian society.
\end{abstract}

Keywords: rule of law, human rights and freedoms, constitutional guarantees, legislation, Constitutional Court

\section{INTRODUCTION}

The ensurance of human rights in the field of research is relevant in many international and national contexts. The state under the rule of law or the principle of the rule of law is one of these contexts. The concept of the rule of law is a complex principle, one of the most contested ones ${ }^{1}$. It is disputable not only in political science but in scientific articles of law also in both theory and empirical analysis, this concept (in many of it's variations) is used worldwide.

* Research Fellow of the Legal System Research Department at the Law Institute of Lithuania. E-mail: lina.beliuniene@teise.org

${ }^{1}$ Essentially contested concepts are defined as such that 'inevitably involve endless disputes about their proper uses on the part of their users' in David, Fernando and Andra (2006) 214. Despite its nearly universal appeal, rule of law, like human rights, is recognized as an essentially contested concept also in Peerenboom (2005) 830. Like many other important moral, political and legal ideals, among them democracy, justice and liberty, the rule of law meaning, scope, conditions and significance are all highly, perhaps essentially, contested. See for it in Waldron (2002) 137-64 and Krygier (2013) 52. 
Emphasis on the fundamental role of the rule of law in protecting human rights is crucial at both international and national levels. This concerns especially the countries of Central and Eastern Europe which have joined the family of democratic states governed by the rule of law after the the fall of the iron curtain. ${ }^{2}$ Although these countries are modeling their specific ways while implementing the rule of law and democracy, ${ }^{3}$ a practical example of the importance of the rule of law for democracy building is the fact that the rule of law is a fundamental principle embraced in most modern democracies, also in the constitutions of the countries of this region including the Republic of Lithuania. These constitutions contain the fundamental and, most often, supreme law of the State, and the rule of law dictates the enforcement of constitutional principles including the principle of protection of human rights above all other laws. ${ }^{4}$

The state of Lithuania is obliged by the Constitution to ensure protection of human rights by legal, material, organizational measures from unlawful encroachment or restriction of human rights, to establish sufficient measures of human rights. ${ }^{5}$ These rights are not always guarantieeed in an appropriate and sufficient way. What shortcommings of legal regulation ensuring separate civil and economic rights are identified in Lithuania? What recommendations could be formulated in order to improve the most problematic areas of ensuring those rights in Lithuania? The author of this article believes that the answers to these questions is important in several aspects. Firstly, sharing of negative experiences, i. e. sharing the examples of some kind of legal regulation and practical failure to ensure the rights in question. These examples then could be used as instances of how not to do it and act as a detterent. Secondly, the discussion about possible measures in different situations to strengthen the protection of human rights could be developed considering the implementation of those measures according to various constitutional regulation instruments of states, different legal traditions, cultural, political and other peculiarities of states.

The purpose of this article is to provide insight into the analysis of the shortcommings of ensuring separate human rights legal regulation in Lithuania while implementing the rule of law. The author introduces some of the results of the legal analysis of the problems of ensuring human rights in Lithuania. In parallel this article is based on the monograph entitled 'The Most Relevant Problems of Ensuring of Human Rights in Lithuania 20082013: ${ }^{6}$ Legal Research' which was prepared by eleven authors from the Law Institute of

2 Krygier (2013) 52.

3 One study of a larger volume on this question could be mentioned: Czarnota, Krygier and Sadurski (2006).

${ }^{4}$ UN Chronicle. The Magazine of the United Nations. Rule of Law and Democracy: Addressing the Gap Between Policies and Practices. Available at: <http://unchronicle.un.org/article/rule-law-anddemocracy-addressing-gap-between-policies-and-practices/>.

5 This obligation is set out in the Ruling of 19 August 2006 of the Constitutional Court of the Republic of Lithuania.

${ }^{6}$ It should be noted that this research covers the first half of 2013. 
Lithuania $^{7}$ last year. ${ }^{8}$ In this monograph the systematic research of thehuman rights situation in Lithuania was set out. It revealed the set of problems related to the laws and other legislation and the practical ensurance of civil, political, economic, social and cultural rights and freedoms. ${ }^{9}$

In general terms the monograph is based on assumption that not all the guarantees of human rights enshrined in the Lithuanian legal system and practice are appropriate. The monograph further argues that it is possible to distinguish the most problematic issues of human rights legislation and the practical steps to ensuring of protection as well as formulating recommendations on how to improve those issues.

In the mentioned monograph the authors deal with problematic aspects of providing the state-guaranteed secondary legal aid in different cases, ${ }^{10}$ the right to physical freedom in the context of a persons detention guarantees, the right to freedom from torture and cruel, inhuman or degradating treatment or punishment in the context of the conditions of imprisonment, protection from domestic violence, the right to privacy, the right to freedom of expression, the right to freedom of thought, conscience and religion, the right to property, the right to directly participate in the governance of the state, ${ }^{11}$ the right to freedom of individual economic activity and initiative, consumer rights, the right to work, the right to social security, the right to the protection of family, the right to health protection in the light of provision of health services and the right to safe environment, the right to education.

The authors of the monograph performing the research firstly revealed a set of problems related to the legal regulation and practical ensurance of separate civil, political, economic, social and cultural rights and freedoms. In addition the authors identified some positive changes in the legal regulation and practical ensurance of those rights during the studied period. After that they performed an analysis of two-three of the most problematic issues of legal regulation and practical ensurance of those rights and recommended solutions.

7 The Law Institute of Lithuania is a research establishment, founded in 1991 by the Government of the Republic of Lithuania seeking to coordinate the reform of the legal system and law institutions, to combine it with the economic and social reorganization carried in the country. The main aims of the Institute are to contribute: to the formation of the scientific basis for the reform of the Lithuanian law and legal system as well as its separate elements based on the national experience and the advantages of the European Law development; to contribute to the safeguarding of human rights and freedoms by elaborating national scientific studies as well as applied scientific researches in the field of law and legal system; to the formation of favorable conditions for business by means of legal measures. The main areas of research of the Law Institute are as follows: public law (paying most attention to the problems of constitutional law and criminal justice) and criminology (paying most attention to the problems of the rights of children and youth). The further information about the Institute is available at: $<$ http://teise.org/About_us.html $>$.

${ }^{8}$ Beliūnienè (2014) <http://www.teise.org/data/zmogaus-teises.-galutinis-2014-10-08.pdf $>$.

9 The systematic character of this research distinguishes this monograph from previous works on human rights topic in Lithuania.

10 Other problematic aspects of ensuring of a right to a fair trial were examined in a separate scientific study of Lithuanian Law Institute by Baltrimas, Lankauskas and Šneideris (2012) < http:// www.teise.org/data/1Teises_i_teisinga_teisma_uztikrinimo_problemos.pdf $>$ (with English Summary).

11 The aspects of the problematic issues of implementation of the right of elections are examined in a separate scientific study of Lithuanian Law Institute by Baltrimas and Kavoliūnaitè-Ragauskienè $(2013)<$ http://www.teise.org/data/Teise_dalyvauti_valdant_sali.pdf $>$ (with English Summary). 
The authors analysed a wide range of relevant issues: those which are not solved, although the state recognized the need to address them; those whose solutions are treated as completely inappropriate; those whose solutions, according to the authors, could be more appropriate and effective; less relevant problems, compared with the ones stated before, whose proper solution may be a sufficient step to strengthening the guarantees of human rights.

Authors of the research referred not only to the analysis of legal acts and other documents (i. e. international and national research, reports, reviews, jurisprudence of international and national courts), statistical data, scientific literature, but also to interviews with experts in different areas. The most frequent publications in the Lithuanian news portal 'Delfi' in recent years, related to human rights issues, or publications which have reached the maximum number of comments and the data of public opinion surveys about the implementation of certain human rights were also considered.

In the first part of this article the author shortly introduces the national context of protecting of human rights: the constitutional requirements for ensuring the human rights and the rule of law and their implementation. In the second part of this article examples of the cases of failure to ensure appropriate or sufficient legal regulation of three constitutional rights selected from the monograph are presented. Although these rights are quite different by their nature - two civil rights (i. e. the right to freedom from torture and cruel, inhuman or degradating treatment or punishment in the context of conditions of imprisonment, the right to freedom of expression and information) and one economic right - the right to freedom of individual economic activity and initiative, these examples are identified as particular cases of violations of requirements of the principle of rule of law. They could be named 'the most striking' because the constitutional requirements for the ensuring of human rights are explained accurately in the vast Lithuanian constitutional jurisprudence, but they are not sufficiently obeyed. In the second part of this article the author reveals the recommendations of how to solve the specifically mentioned shortcommings of the legal regulation. The author of this article mainly describes the conducted research. In addition, she uses scientific legal literature relevant to the topic of this article. This article respectively is also based on the provisions of the Constitution of Republic of Lithuania and acts of the Constitutional Court of the Republic of Lithuania (i. e. decisions and rulings).

It is necessary to explain that some problems detailed in this article can be viewed retrospectively, i. e. those problems have been already successfully solved or are dealt with in smaller or larger steps. ${ }^{12}$ Nevertheless, the review of those problems does not lose their significance because they are important as the examples what not to follow. Although attention could begiven to the fact that during a long period of the research (the research lasted for more than two years) the list of analysed problems was reviewed, non-relevant problems were removed from this list and the others included. This allowed fixing the changes of the analysed sphere, the development of smaller or bigger steps of state in it. It must be recognized that the authors of the research performing this researh faced considerable challenges due to the fact that thenecessary steps to ensuring human rights analysed in the monograph were not rare. The monograph also invites one to recognize the fact that a permanent development of legal regulation in general is one of the characteristic features of the legal system and that this development depends on societal changes. ${ }^{13}$

12 Separate changes are mentioned in the second part of this article.

13 The fact that a permanent development of legal regulation in general is one of the characteristic features of the legal system and that this development depends on the societal changes was stated by the Constitutional Court of the Republic of Lithuania in the Ruling of 13 November 1997. 
Speaking about the research it is important to emphasize that not all shortcommings of legal regulation are determined by acts issued or acts not issued by the subjects of legislation and not all problems of human rights existing in the state could be solved by legal measures, that other non legal measures are also necessary. The appropriate perception of human rights by the subjects of such rights and the representatives of the state institutions, raising public legal awareness and many other aspects are important although they are reflected only in a small part as far as it is necessary to maintain the integrity of the results of the presented monograph.

\section{THE CONSTITUTIONAL REQUIREMENTS FOR ENSURING HUMAN RIGHTS AND THE RULE OF LAW AND THE SITUATION OF THEIR IMPLEMENTATION}

\subsection{Constitutional protection of human rights}

Untill 1992 when the Constitution of the Republic of Lithuania was adopted (which is still in force with subsequent amendments and supplements), Lithuania was bound by the obligations under the Universal Declaration of Human Rights, International Covenant on on Civil and Political Rights and International Covenant on Economic, Social and Cultural Rights, Optional Protocol to the International Covenant on Civil and Political Rights. Later Lithuania ratified the European Convention for the Protection of Human Rights and Fundamental Freedoms and the European Social Charter (revised). Lithuania became a member of the European Union in 2004. The state is participates in the implementation of many other international instruments prepared by the European Council, United Nations and European Union and other international organizations. ${ }^{14}$ These and other international instruments and the judicial practice explaining them became the sources of interpretation and application of law in Lithuania. According to the Constitutional Court of Lithuania, the jurisprudence of the European Court of Human Rights as a source of construction of interpretation is also important to the application of Lithuanian law. The same can be said with regards to the jurisprudence of the Court of Justice of the European Communities and the Court of First Instance of the European Communities. ${ }^{15}$

The content of the 1992 Lithuanian Constitution was influenced by national historical and international factors. These influencing factors were: ideas of democratic human rights and freedoms and the restoration of independence to the Lithuanian state which were matured and disseminated by Lithuanian national resistance to political regime in the battles of the second half of the last century; constitutional democratic heritage of the Republic of Lithuania of 1918-1940, the constitutional values of European and other countries of the world. ${ }^{16}$

Fundamental human rights are entrenched mainly in the preamble of the Constitution, II Chapter (entitled "The Human Being and the State"), III Chapter (titled 'Society and the State'), IV Chapter (titled 'National Economy and Labour') and XIII chapter (titled 'Foreign

14 For a detailed list of such international agreements in English, see the link of the Ministry of Foreign Affairs of the Republic of Lithuania. Available at: <https://www.urm.lt/default/en/foreignpolicy/treaties/bilateral>.

15 Constitutional Court of the Republic of Lithuania in the Ruling of 21 December 2006.

16 Žilys (2013) <http://www.lrt.lt/naujienos/kultura/26/12807/kelias_i_lietuvos_respublikos konstitucija_pagrindiniai_teisiniai_politiniai_zenklai>. 
Policy and National Defence'). ${ }^{17}$ The Constitution comprises a wide catalogue of human rights including civil, political, economic, social and cultural rights and a wide doctrine of these rights were developed in the jurisprudence of the Constitutional Court of the Republic of Lithuania. It is recognized that this catalogue is broadly consistent with international standards of human rights entrenched in the Universal Declaration of Human Rights, International Covenant on Civil and Political Rights and International Covenant on Economic, Social and Cultural Rights, the European Convention for the Protection of Human Rights and Fundamental Freedoms and others. ${ }^{18}$

The doctrine of human rights in Lithuania was formed as part of European human rights culture based on the provisions of natural human rights. ${ }^{19}$ According to article of 18 of the Constitution which is the first article in the I Chapter, 'human rights and freedoms are natural'. This provision is one of the basic provisions of the democratic constitutional order and the recognition and implementation of human rights is regarded as a necessary element of an open, just, and harmonious civil society and state under the rule of law. ${ }^{20}$ The Lithuanian state by recognizing the natural status of human rights and freedoms has committed itself to respect them and to obey them, to ensure their defense and to protect them from any illegal encroachment or limitation.

The State commitments are disclosed also in the other articles of the Constitution, in the other legal acts dedicated for the implementation of human rights. One of the obligations of the legislature is to establish sufficient limits for constitutional rights and the guarantees for them. So human rights and freedoms are related to the responsibility of state institutions for the system of guaranteing human rights and are related to the defense of the violation of rights.

The laws (which are enacted by legislature) regulate relations in connection with human rights. These laws comprises the confirmation of human rights and freedoms, determination of the contents thereof, legal guarantees of protection and defence, their permissible limitation, etc. ${ }^{21}$ The legislature is responsible for those areas which do not denythe reponsibility of other subjects which participate in the ensurance of human rights. The questions related to procedural relations, order of implementation of separate human rights and other similar questions ${ }^{22}$ are regulated mainly by by-laws issued not only by the Lithuanian Parliament (Seimas), but by the President or the Government of the Republic or adopted in a referendum and by ministries, departments and other state institutions, local government and other municipalities institutions.$^{23}$ This means that this regulation by bylaws ould be potentially widely questioned if it is appropriate and sufficient. ${ }^{24}$

17 The text of the Constitution in English is available at $<$ http://www.lrkt.lt/en/about-the-court/ legal-information/the-constitution/192>.

18 Jarašiūnas (1999) 27.

19 Birmontienè (2000) 66; Miliauskaitè (2004) 105-106.

20 Jarašiūnas (1999) 27.

21 The Constitutional Court of the Republic of Lithuania Ruling of 19 December 1996.

22 According to the Rulings of 13 December 2004, 5 May 2007 of the Constitutional Court of the Republic of Lithuania.

23 Küris (2012) 76.

24 For example, according to the Constitution of Lithuania, the Constitutional Court of the Republic of Lithuania decides whether the laws and other acts of the Seimas are in conflict with the Constitution and whether the acts of the President of the Republic and the Government are in conflict with the Constitution or laws. Administrative courts decide on acts of lower legal force issued by the executive power and acts issued by local government institutions. 
Article 6 of the Constitution stresses that the Constitution shall be an integral and directly applicable act, that everyone may defend his rights by invoking the Constitution. The system of institutions in which the Lithuanian citizen can defend their rights is constitutional. The system of institutions comprises constitutional justice which is implemented by the Constitutional Court defending the rights entrenched in the Constitution concerning violations made by state institutions, the system of courts including the local and regional courts and the Supreme Court of Lithuania, the Court of Appeal of Lithuania and the system of special administrative courts; complaints of citizens about the abuse of authority and bureaucratic intransigence by State and municipal officials (with the exception of judges) shall be examined by the Parliament (named 'Seimas') ombudsmen and other institutions.

The fact that this system of guarantees could not be regarded as sufficient for ensuringhuman rights in Lithuania is based on at least a few circumstances related to institutional aspects concerning the protection of human rights. Firstly, the fact that Lithuania still does not have a legal system by which there exists an institute for constitutional complaintwhich could improve the protection of human rights (it could provide opportunities to identify potential unconstitutional norms in the system of law more effectively and to overcome unwillingness of the courts in some cases to initiate the submitting of motivated applications of persons to the Constitutional Court of the Republic of Lithuania). Secondly, not enough steps have been taken towards finding solutions to the questions of how to establish a National Human Rights Institution which could promote improving the protection of human rights.

Ensuring the implementation of human rights involves an active role on the part of the state which is indispensable.

\subsection{Constitutional characteristics of the state under the rule of law}

The mentioned ideas for the close relationship between ensuring human rights and the state under the rule of law ${ }^{25}$ suggests that the rule of law can be regarded as a foundation for the systematic analysis of the quarantees of ensuring of human rights and respectively assessing the shortcommings of guaranteeing human rights. ${ }^{26}$ So the cases of failure to ensure and the

25 For the detailed analysis of this relationship please look at Peerenboom (2005) 831.

26 Although the various indicators of the measurement of the implementation of the state under the rule of law are conducted by international organizations which evaluate the progress of such an implementation, this measurement also includes the identification of shortcommings of ensuring human rights in order to improve the situation related to human rights. We can refer to two examples of such indicators. Firstly, the Rule of Law Indicators which are prepared by the United Nations. While they are based on quite a wide conception of the rule of law articulated by the United Nations Secretary-General in a report to the Security Council in 2004 for the purpose of the first edition of such an Indicators (2011), they comprise a set of indicators having a more limited scope. Available at 'The United Nations Rule of Law Indicators. Implementation Guide and Project Tools' (2011) <http:// www.unrol.org/document_browse.aspx? $x d=1 \&$ cat_id=2>. Secondly, the checklist for evaluating the state of the rule of law in single states prepared by the experts of the Venice Commission speaking of consensual core meaning of the rule of law and the elements contained within it drawing on definition of Bingham (2010) and on others based on very different systems of law and the state, finding a consensus for the necessary elements of the rule of law as well as those of the Rechtsstaat which are not only formal but also substantial or material. Available at 'European Commission for Democracy Through Law (Venice Commission) Report on the Rule of Law adopted by the Venice Commission at its 86th plenary session' (Venice, 25-26 March 2011). 
cases of violation of the requirements of this principle were chosen by the authors of the mentioned monograph as the criteria for the evaluation of non-ensurance of human rights.

In the Constitution of the Republic of Lithania (as almost in all of the Constitutions of states of the region of Central and Eastern Europe ${ }^{27}$ ) this principle is declared in the preamble by words 'striving for an open, just, and harmonious civil society and State under the rule of law' and manifests in many other provisions of the Constitution as well. The doctrine of legislation developed by the Constitutional Court is based on this principle and the requirements for it (different elements of the principle of the rule of law are revealed in the decisions of the Constitutional Tribunal of Poland, the Constitutional Court of Hungary, the Constitutional Court of Slovenia and other Constitutional Courts ${ }^{28}$ ). The view should be agreed with that the state could be characterized as the rule of law. It is easy to guarantee the principles of the rule of law but it its one of the most complicated tasks of the society and government institutions of those countries. ${ }^{29}$ It must be admitted that the constitutional parameters of the rule of law do not in themselves indicate to what amount the state ensures economic, social and cultural rights, what social policy is implemented; the differences that exist between the rule of law as the constitutional principle and the rule of law as the real state of society. ${ }^{30}$

Furthermore, it could be noted that in the constitutional jurisprudence of the Republic of Lithuania the principle of the state's social orientation ${ }^{31}$ is disclosed beside the principle of the rule of law (the Constitutions of the other states of the region of Central and Eastern Europe characterizes the state as the social state). ${ }^{32}$ Although the author of this article does not examine the shortcommings of ensuring of social rights (as well as of cultural rights; although these issues were dealt with in the presented monograph), in the context of the difference between the rule of law state and the socially oriented state it can be noted that even in the constitution of the state the broad social guarantees are consolidated the state will be the rule of law state only if those guarantees were actually ensured . The treatment of the rule of law state firstly as the real state of society allows it to expand a spectrum of it's parameters so as it could cover the actual defence of human rights; although such an analysis is the object of political theory and legal sociology, not the constitutional law ${ }^{33}$ and although such an analysis is performed only in a small part in the presented monograph, this monograph and this article focus mostly on the examining of problems from the perspective of law.

When construing the content of the constitutional principle of a state under the rule of law, the Constitutional Court of Lithuania has held more than once in its rulings that the constitutional principle of a state under the rule of law is a universal principle, upon which the entire legal system of Lithuania and the Constitution of the Republic of Lithuania itself

27 It could be noted that unlike in Lithuania the Fundamental Law of Hungary uses the term 'democratic State under the rule of law". The Fundamental Law of Hungary (25 April 2011), Article B. Available at: <http://www.mkab.hu/rules/fundamental-law > .

28 Jarašiūnas (2002) 54.

29 Jarašiūnas (2002) 53-54.

30 Kūris (2002) 65-67.

31 For example, in the ruling of 7 February 2005 of the Constitutional Court of the Republic of Lithuania the Constitutional Court notes that according to the Constitution the state of Lithuania is socially oriented.

32 Jarašiūnas (2002) 54.

33 Kūris (2002) 65-67. 
are based; that the essence of the constitutional principle of a state under the rule of law is the rule of law. The constitutional imperative of the rule of law means that the freedom of state power is limited by law, to which all the entities of legal relations, including the lawmaking entities, must obey. It is to be stressed that the discretion of all the law-making entities is limited by the supreme law - the Constitution. All the legal acts, decisions of all the state and municipal institutions and officials must be in compliance with and not contradicting the Constitution. ${ }^{34}$

The Constitutional Court has held that the constitutional principle of a state under the rule of law must be followed both in law-making and enforcement of law. ${ }^{35}$ The compliance of each institute of law with the Constitution must be evaluated according to how this institute is in compliance with the constitutional principles of a state under the rule of law. ${ }^{36}$ Just like the content of the constitutional principle of a state under the rule of law is to be interpreted without denying any single provision of the Constitution. In the same way none of the provisions of the Constitution - not a single constitutional principle or constitutional norm - may be interpreted so that this interpretation would deviate from the requirements of a state under the rule of law which arise from the Constitution. On the contrary the content of the constitutional principle of a state under the rule of law, thus the constitutional concept of a state under the rule of law, would also be distorted or even denied. All the provisions of the Constitution are to be applied in the context of the constitutional principle of a state under the rule of law, and enshrined in the constitutional concept of a state under the rule of law. It is the function of the constitutional doctrine to reveal the content of the concept of a state under the rule of law. ${ }^{37}$

According to the Constitutional Court the constitutional principle of a state under the rule of law is an especially voluminous constitutional principle, which comprises lots of various interrelated imperatives. Thus, it should be stressed that the content of the constitutional principle of a state under the rule of law is to be revealed while taking account of various provisions of the Constitution. This should be done while evaluating all the values entrenched in, and protected and defended by the Constitution, and while taking account of the content of various other constitutional principles, such as the principle of the supremacy of the Constitution, its integrity and direct applicability, sovereignty of the Nation, democracy, responsible governance, restriction of powers of state authority and service of state institutions to the people, publicity of law, justice (comprising inter alia natural justice), separation of powers, public spirit, equality of persons before the law, court, state institutions and officials, respect to and protection of the human rights and freedoms (comprising inter alia the recognition that the human rights and freedoms are of innate nature), coordination of interests of the person and society, secularity of the state and its neutrality in world-view matters, social orientation of the state, social solidarity (comprised with responsibility of everyone for his own fate), and other constitutional principles of no less importance. The constitutional principle of a state under the rule of law is consolidated not only by the striving for an open, just, and harmonious civil society and state under the rule of law, which is declared in the Preamble to the Constitution, but, in various aspects, by all the rest of the provisions of the Constitution as well. ${ }^{38}$

\footnotetext{
34 The Constitutional Court of the Republic of Lithuania Ruling of 13 December 2004.

35 The Constitutional Court of the Republic of Lithuania Ruling of 6 December 2000.

36 The Constitutional Court of the Republic of Lithuania Ruling of 11 May 1999.

37 The Constitutional Court of the Republic of Lithuania Ruling of 11 May 1999.

38 The Constitutional Court of the Republic of Lithuania Ruling of 13 December 2004.
} 
As it was mentioned according to Lithuanian constitutional jurisprudence the constitutional principle of rule of law presupposes the requirement to ensure human rights and freedoms both in lawmaking and in its implementation. Revealing the specific requirements of the rule of law it should be noted that for example some elements of the official constitutional doctrine of lawmaking are mostly developed on a case by case basis by the Constitutional Court of the Republic of Lithuania. Basically, one can draw a list of those elements hich is not exhaustive: (i) the stability of the legal regulation and its development; (ii) the presumption of constitutionality, legality of the legal acts and the obligation of legislative subjects to continuously adjust legislation within their competence to the Constitution; (iii) the imperatives of the coherence of law (iv) the imperatives of legal clarity, legal certainty and legal security also lex non cogit ad impossibilia and protection of legitimate expectations; (v) legal publicity, the interdependence of legislative promulgation and validity of legal acts; (vi) the form of legal acts and hierarchy of normative legal acts; (vii) the period of validity of legislation in time and lex retro non agit, also limitation on suspension of the laws; (viii) permanent and ad hoc legal regulation; (ix) the absence of delegated legislation, the elaboration of higher legal force provisions in the acts of lower force; (x) competition of legal regulation - vertical and horizontal aspects, general and exceptional legal regulation; (xi) differentiated legal regulation; (xii) the relationship of material and procedural legal regulation and their interdependence; (xii) the structure of normative legal acts; (xiii) the legislative technique including the usage of concepts and their definitions in the legal acts. ${ }^{39}$

\section{THE CASES OF IDENTIFIED VIOLATIONS OF REQUIREMENTS OF THE RULE OF LAW}

Although it could be concluded that the rights most obviously connected to the rule of law are related to 'thin' or 'formal' conception of the the rule of law, ${ }^{40}$ the author of this article believes that in order to strengthen the ensurance of the human rights both conceptions of the rule of law - 'thin' or 'formal,' and 'thick', 'substantive', or 'material' - as integrating the essense of this principle are needed. While the former limit themselves to formal properties of laws and legal institutions, that are purported to constitute the rule of law, the latter require substantive elements from a larger vision of a good society and polity democratic, free-market, human rights respecting, to be present. ${ }^{41}$ This position reveals the chance to analyse the ensuring of different kinds of human rights.

39 Kūris (2002) 75.

40 According to the mentioned Report on the Rule of Law adopted by the Venice Commission, the rights most obviously connected to the rule of law include: (1) the right of access to justice, (2) the right to a legally competent judge, (3) the right to be heard, (4) inadmissibility of double jeopardy (ne bis in idem) (Article 4 of Protocol 7 to ECHR), (5) the legal principle that measures which impose a burden should not have retroactive effects, (6) the right to an effective remedy (Article 13 ECHR) for any arguable claim, (7) anyone accused of a crime is presumed innocent until proved guilty, 48 and (8) the right to a fair trial or, in Anglo-American parlance, the principle of natural justice or due process; there has to be a fair and open hearing, absence of bias, and a reasonable period within which the case is heard and decided. Additionally, there must be a recognised, organised and independent legal profession, which is legally empowered, willing and de facto able to provide legal service, and the decisions of which are implemented without undue delay.

${ }^{41}$ Krygier (2013) 52. 
As it was already mentioned in the second part of this article the author presents the examples of the cases of inappropriate or insufficient legal regulation of three constitutional rights selected from the monograph. These examples could be named 'the most striking' because the constitutional requirements for the ensurance of human rights are explained accurately in the wide Lithuanian constitutional jurisprudence, but they are not sufficiently obeyed. Although the selected rights are quite different in their nature - two civil rights (i. e. the right to freedom from torture and cruel, inhuman or degradating treatment or punishment in the context of conditions of imprisonment, the right to freedom of expression and information) and one economic right (the right to freedom of individual economic activity and initiative), these examples are identified as particular violations of the requirements of the principle of rule of law.

The analysis made in the mentioned monograph identified some specific cases of noncomplexity/non-systematicity, inconsistency, intricacy, uncertainty, and often - instability, unconstitutionality, and in some cases nonconformity with international standards of human rights protection, as well as the inaccessibility of legal regulation. Almost the whole complex of those specific shortcomings is reflected in the sphere of implementation of the constitutional economic right - the right to freedom of individual economic activity and initiative. ${ }^{42}$ So this sphere is overviewed in this article firstly and wider than the situation of implementation as compared to any of the other selected areas to present human rights and freedoms ${ }^{43}$ After this the situation of two civil rights (i. e. the right to freedom from torture and cruel, inhuman or degradating treatment or punishment in the context of conditions of imprisonment, the right to freedom of expression and information) is analysed. The situation of ensuring the latter rights could be compared with that of the situation of ensuring the former rights which is less complicated..

\subsection{The right to freedom of individual economic activity and initiative}

In the section of 4.1 titled 'The right to freedom of individual economic activity and initiative' the mentioned monograph analyses three relevant problems that cause difficulties in the exercise of this right: 1) insufficient understanding of importance of freedom of individual economic activity; 2) shortcommings of legal regulation of limitations of economic activity; 3) lack of legal guarantees in applying economic sanctions for entrepreneurs. According to the topic of this article the shortcommings of legal regulation of limitations of economic activity and the lack of legal guarantees in applying economic sanctions for entrepreneurs are relevant. They are specified further.

The research found flawed practice in limiting the freedom of individual economic activity and initiative by the acts of lower force than the laws. For example, the duties of the builder, designer, contractor, owner or user of engineering and utility networks, owner or user of cultural heritage object and duties of other persons and the limitations of specific economic activities are established in separate laws of the Republic of Lithuania (Law on Construction, Law on Environmental Protection, Law on Water, Fisheries Act, Law on the Protection of Immovable Cultural Heritage and other laws) but they are regulated also by 87 technical construction regulations issued by the Minister of Environment of Lithuania

42 It is presented on the basis of the monograph, 150-161.

43 Although the problems of ensuring of civil rights and freedoms are analysed firstly in the presented monograph. 
and were issued, amended, and repealed 178 times. ${ }^{44}$ Similarly, various economic activities are limited in different areas of personal and public health by hygiene norms approved by Minister of Health of the Republic of Lithuania which were issued, amended, and repealed 176 times during the period of the preparation of the presented monograph. ${ }^{45}$ The legal acts regulating economic activity and limiting it are prepared and approved by orders of specific ministeries not only by ministeries which are policy-making institutions (i. e. which are empowered to decide certain questions or offer solutions according to their field of competence), but also by such institutions of the state which implement policies in different separate areas and apply legal acts, for example, supervising institutions (inspectorates, offices, commissions, etc.) of economic entities.

The aforementioned situation leads to a number of problems. Firstly, in the preparing of such draft legislation the order of coordinating such draft legislation with the public, business associations, public authorities it is not set and frequently not applied which would be binding in preparing and coordinating the resolutions of the Government of the Republic of Lithuania and the draft laws. Thus, there are not enough safeguards ensuring that restrictions of the right to freedom of economic activity and initiative established in such legal acts are reasonable, proportionate and would comply with the regulation established by the laws and the Constitution of the Republic of Lithuania.

Secondly, while those acts are issued by one institution there is a lack of a mechanism which could limit frequent amendments of legal acts. This frequent amending causes an additional regulatory burden for entrepreneurs. Failure to comply with the statutory requirements, results in entrepreneurs being subject to sanctions so the entrepreneurs are required to constantly follow the changes in legislation. The more frequent the changes are in legislation, the greater the burden is for entrepreneurs, the lower the legal stability is.

The adaptation burden for entrepreneurs is even greater in cases when legal acts and their amendments enter into force immediately after their adoption and publication without the period during which the entrepreneurs could have access to the act and prepare for its application. Non establishment of such a transition period is the third problematic aspect as a consequence of such legal regulation.

Fourthly, the entrepreneurs are faced with the problem of accessibility to the legislation. In cyberspace it is not published and provided for free in one (i. e. in one web page) relevant consolidated (valid) version of legal acts of lower legal force. In the e-portal of the Lithuanian Parliament Seimas only consolidated valid versions of the laws and the regulations of the Government are published. So possibilities for entrepreneurs and other subjects to have access to the acts of lower legal which are in force are limited. Ministries and other state institutions publish legal information in different ways, sometimes only formally. The Law on the Fundamentals of Legislation of the Republic of Lithuania which must ensure the guarantee of announcement of the consolidated valid versions of all legal acts for free in one web page and respectively the better accessibility of legal regulation for the society inter alia for the entrepreneurs came into force on the 1st of January in 2014.

44 According to the data provided by the e-portal of Lithuanian Parliament Seimas and Ministry of Environment of Lithuania. Available at <http://www3.1rs.1t/dokpaieska/forma_1.htm>, <http:// www.am.lt/VI/index.php\#a/12476>.

45 According to the data provided by the e-portal of Lithuanian Parliament Seimas. Available at $<$ http://www3.1rs.1t/dokpaieska/forma_1.htm $>$. It should be noted that the researchers did not find a collection of norms of Hygiene which would be prepared according to the e-portals of the state institutions from which it would be clear the total amount of the valid norms. 
However, it could be stated that during the period of the presentation of themonograph the entrepreneurs were not properly informed. The Constitutional Court of The Republic of Lithuania while analysing the limitations of legal regulation on economic activity has noted that information about the restrictions or prohibitions should be public, legal subjects must be informed about them in advance; otherwise, the constitutional principle of legitimate expectations would be ignored. ${ }^{46}$

The aforementioned practice showed that the imperative developed by the Constitutional Court of the Republic of Lithuania, namely that restrictions of human rights and freedoms must be established in law, is ignored. Also, the aforementioned practice does not ensure the constitutional principle of legitimate expectations and preconditions are created to restrict freedom of economic activity too much.

As also noted by the Constitutional Court of the Republic of Lithuania the freedom of economic activity may be restricted in order to defend the interests of the consumers, to protect fair competition, and other values enshrined in the Constitution. It is inadmissible to deny by limitation such basic provisions of freedom of economic activity as equality of the entities of economic activity and fair competition; the state may not interfere in individual economic activity in an unlimited manner. ${ }^{47}$

In the process of evaluating the laws of the Republic of Lithuania which are important for implementing the mentioned freedom it could be noticed that only in certain laws (for example, in the Civil Code, in the Law on Small and Medium-Size Business Development, in the Law on Public Administration, in the Law on Services) the balance between the rights conferred to entrepreneurs and their duties is maintained. In most other laws of the Republic of Lithuania, in particular special laws regulating separate economic activities (in the laws on taxes, in the Law on Competition, in the Law on the Register of Legal Entities, in the Law on Public Limited Liability Company, in the Law on Individual Enterprises, in the Law on Partnerships, in the Law on Financial Statements of Entities, in the Law on Tax Administration, in the Enterprise Bankruptcy Law, in the Law on Restructuring of Enterprises, in the Law on the Assessment of the Effects of Economic Activities on the Environment and other laws) the scope of obligations set for entrepreneurs is often much wider than the set of rights and guarantees. For example, in the Law on the Construction the number of obligations set for the builder (client) is 12 and he has only 3 rights (according to article 12 of this $\mathrm{Law}^{48}$ ); the number of the duties of the designer of a construction works is $8^{49}$ and he has only 3 rights (according to article 14 of this Law); the number of the duties of the contractor is $8^{50}$ and he has 3 rights (according to article 15 of this Law); only restrictions, prohibitions and the responsibility for food producers, processors, suppliers, dealers, etc. are enshrined in the Law of Food. ${ }^{51}$

46 The Constitutional Court of The Republic of Lithuania Ruling of 21 January 2008.

${ }^{47}$ See, for example, The Constitutional Court of the Republic of Lithuania Rulings of 20 April 1995, 13 May 2005, etc.

48 Official Gazette, 1996, No. 32-788 (with subsequent amendments and supplements).

49 Since the 1st of January of 2014 the amendment of article of 14 of this Law entered into force and it annuled the eighth duty of the designer (i. e. the duty to participate in acceptance of a construction works as fit for use), so the number of duties of the designer remains 7 .

50 Since the 1st of January of 2014 the amendment of article of 14 of this Law entered into force and it annuled the eighth duty of the contractor (i. e. the duty to participate in acceptance of a construction works as fit for use), so the number of duties of the contractor remains 7 .

51 Official Gazette, 2000, No. 32-893 (with subsequent amendments and supplements). 
It is summarized in the monograph that if such a tendency fixed in the mentioned laws - firstly, to limit the freedom of economic activity than to entrench the guarantees of this freedom - is observed as transferred to the acts implementing the laws it should raise reasonable doubts as to whether the right to freedom of economic activity and initiative is not too restricted.

In the monograph the problem of the lack of legal security in the sphere of licensed economic activities is separately discussed. Taking into consideration the reason that licensing of economic activities is related to stricter supervision of economic activity, to the greater accountability of entrepreneurs, licensing must be regarded as a special economic activity limitation. This limitation must only be applied in exceptional cases when it is necessary to protect the important interests of the society (human health, life, public order, public safety, etc.) and when there is no other less restrictive means to address the problem identified. The chosen regulatory instrument - licensing of activities - must furthermore not restrict the rights and freedoms of entrepreneurs more than is necessary to achieve the clearly outlines objectives .

Briefly listing the deficiencies in this mentioned field of legal regulation and its practical ensurance three problems could be noted. The first problem is that there are a lot of institutions acting independently which can issue permits, licenses, certificates (for example, the Bank of Lithuania) or institutions subordinated to different ministries (to the Ministry of Environment, to the Ministry of Energy, to the Ministry of Finance, to the Ministry of Culture, to the Ministry of Social Security and Work, to the Ministry of Transport, to the Ministry of Health Protection, to the Ministry of Education and Science, to the Ministry of Justice, to the Ministry of Economy, to the Ministry of Home Affairs, to the Ministry of Agriculture) and there is no single database or compendium, which could allow access to which economic activities the regime of licensing is applicable. The lack of systematic, detailed, consistent information about the licensed economic activities fail to create the conditions for the effective review of legal regulation which could allow the entrepreneurs to implement their right to freedom of economic activity and initiative with fewer constraints and to reduce the level of corruption.

The second problem is that constitutionally significant provisions requiring the types of licensed activities, the foundations and conditions of licensing to be set only by law is entrenched in the act of lower legal force than the law - in the Description of Licensing Foundations, approved by the Resolution of the Government. ${ }^{52}$ This Description states that the right of the entrepreneur to engage in certain activities may be restricted only by the law, i. e. the requirement to have the license, the conditions of the license, the conditions of the licensed activity (including the rights and obligations of the license holders), the grounds on the denial of the license, the suspension of the license, the cancellation of the license suspension and revocation of the licence can only be established by law. ${ }^{53}$ Although the

52 Official Gazette, 2012, No. 90-4697.

53 The new version of the Resolution changed this regulation (which entered into force on 31 of October in 2013; Valstybès žinios, 2013, Nr. 113-5644): the right of the entrepreneur to engage in certain activities may be restricted only by the law, i. e. the requirement to have the license, the conditions of the license, the conditions of the licensed activity (including the rights and obligations of the license holders), the grounds of the denial of the license, the suspension of the license, the cancellation of the license suspension and of the licence revocation can be only established by law. The scope of legal regulation of issuing of licenses and the conditions of licensed activities by the law is determined in accordance with the criterion of reasonableness. The rules of licensing must establish 
content of this provision is beyond doubt, it is clear that the legal force of this provision is not sufficient: this provision is binding only upon the Government, ministries and subordinate institutions while preparing the drafts of legal acts including the laws. This provision is not binding on the independent bodies related to the regime of licenses (for example, for the Bank of Lithuania, the Communications Regulatory Authority, the National Commission for Energy Control and Prices, The State Commission of the Lithuanian Language and the others), it is also not binding for the most important sujects of the legislation - for the members of the Lithuanian parliament Seimas and for the President of the Republic. ${ }^{54}$

The third problematic issue is insufficient implementation of the mentioned provision. The conditions of licensing are enshrined not only in the laws but in the Resolutions of the Government of the Republic of Lithuania and in other legal acts of lower legal force . Although a number of licensing legislation related to Lithuania was reviewed while implementing the European Union Directive on the Services (transfering the restrictions from the acts of the lower legal force to the laws), however, a consistent regulatory review process has not been carried out.

It is summarized in the monograph while analysing the legal regulation of the licensed activities that it is significant that appropriate legal provisions would not become declarations but are implemented actually: that the State Enterprise Centre of Registers would create a common information system which would allow the optimization of the issuing of licenses in the state institutions and to announce the information for the entrepreneurs on the issued licenses and to manage it through a public electronic service as it is specified in the Description of Licensing Foundations, as well as to perform the review of permits (licenses) to economic and commercial activities, the conditions of issuing them and the requirements to them, as it is provided by the national anti-corruption programme of the Republic of Lithuania in 2011-2014. Thereby the restrictions of the implementation of the right to freedom of economic activity and initiative could be reduced as well as the preconditions of corruption in the sphere of relations of entrepreneurs and civil servants.

Characterizing the problem of the lack of legal guarantees while applying the economic sanctions for entrepreneurs as the problematic aspect of this mentioned freedom in the presented monograph it is highlighted and analysed in several aspects: a) uneven and insufficient legal guarantees (material and procedural) originating from the quantity of different laws (for example, the rights of the entrepreneurs are insufficiently ensured in the process of applying of economic sanctions because in the law minimal uniform standards on ensuring the rights of entrepreneurs are not enshrined; the process of the application of economic sanctions is regulated differently by approximately 30 laws; some of these laws

only the requirements related to the implementing procedures of the issuing of the licenses, of the denial of the licenses, of the suspension of the licenses, of the cancellation of the license suspension and of the licence revocation, of the compliance with the conditions of the licensed activity.

${ }^{54}$ In the preamble of the mentioned Resolution it is enshrined that such subjects are guided by the Description of Licensing Foundations: ministries, institutions under the ministries, other state institutions subordinated to the ministries, Government agencies of the Republic of Lithuania and other state institutions and agencies which are accountable to the Lithuanian Government and which prepare the rules regulating the licensing of the economic activity and the drafts of rules of licensing; it is recommended for the public administration entities which are not accountable to the Government of the Republic of Lithuania and which approve the legislation implementing the laws related to the licensing of activity, to be guided by the Description. 
have serious shortcommings); b) fragmented implementation of the acts of the Constitutional Cout of the Republic of Lithuania; c) the preconditions for the lack of uniformed practice of supervising of economic activities.

In the monograph it is recommended that the sufficient legal guarantees for the entrepreneurs should be entrenched in the laws of Lithuania in the process of the applicaton of economic sanctions. The entrepreneur should be informed about the initiation of the investigation process, should have the right to provide an explanation and evidence of his/ her innocence in the process of investigation, should have sufficient time to prepare for the proceedings, the procedural decisions of the state institutions or officials should be motivated, based solely on the evidence collected and properly investigated, etc. This would require a review and modification of the all legal acts regulating the application of the economic sanctions or to entrench minimal (necessary) procedural guarantees for entrepreneurs in a separate law.

It is reccommended as well that public administration entities who apply the economic sanctions should be given a wider discretion to choose a size of a sanction, to decide on the reasonableness and purpose of the measures applicable. The legislature should have a more comprehensive look into the process of applying economic sanctions and systematically rather than fragmentary review the related legal regulation according to the decisions of the Constitutional Court of Lithuania finding the unconstitutionality of a legal regulation and other regulatory shortcommings.

The status of entrepreneurs in the process of applying economic sanctions is burdened not only by the lack of legal guarantees in various legal acts but also by the fact that the supervision of economic activities (including the application of the sanctions) is carried out by many institutions. It is complicated to ensure that in all institutions and their units the uniformed and advanced standards of activities and of administrative punishment would be applied. So the large quantity of those institutions create the preconditions and sometimes actually lead to diverse practice of supervision and administrative punishment of entrepreneurs. This does not guarantee the principles of equality of entrepreneurs before the law, their non-discrimination. It is recommended that a network of supervision institutions should be optimized and here the ministries competent for supervisory authorities should take the first initiative.

\subsection{The right to freedom from torture and cruel, inhuman or degradating treatment or punishment: the conditions of imprisonment}

Three aspects of the problems of ensuring civil rights provided in section of II.2 of the presented monograph and named 'The right to freedom from torture and cruel, inhuman or degradating treatment or punishment: the conditions of imprisonment ${ }^{\prime 55}$ are stated: 1) inappropriate housing conditions for prisoners, 2) insufficient protection from violence of convicts, 3) insufficient protection of vulnerable persons. In this article it is very relevant to characterize the lack of compliance of the Lithuanian national regulation with international requirements. This lack of compliance combines all the aforementioned problematic spheres (although those aspects which are analysed in the monograph also dependon major economic and social investment) and could be the main precondition for ensuring the right to freedom from torture and cruel, inhuman or degradating treatment or punishment. This is also relevant because in the period of the monograph and during a

55 They are described according to the presented monograph, 38-55. 
subsequent period after it the competent international body in their reports on the situation of implementation of this right in Lithuania and the European Court of Human Rights have listed the cases of inhuman or degradating treatment in respect of Lithuania. ${ }^{56}$

International instruments encapsulate the main commitments related to the ensuring of housing conditions: (1) to provide individual cells or rooms for the night sleep for prisoners ${ }^{57}$ (2) to ensure sufficient area (space) of cells for one prisoner; ${ }^{58}$ (3) prohibition to accomodate in cell or room more prisoners than it is allowed with some exceptions, ${ }^{59}$ (4) to ensure sufficient conditions of living space, lighting, heating, ventilation. ${ }^{60} \mathrm{~A}$ big part of the international requirements related to prisoners housing conditions are not entrenched in the legislation of Lithuania.

The legal acts do not provide for the requirement to give the prisoners individual chambers for sleep. The formal legal requirements against the overcrowdeding of prisons and the inability to provide the above-mentioned conditions, is actually unrealizable. Although the minimal space standards for prisoners are entrenched in subordinated legislation, in practice in many cases they are not satisfied due to the problem of overcrowding. In some prisons (especially in pre-trial detention) sufficient conditions of lighting, ventilation, heating and similar conditions for prisoners is not guaranteed. Lithuanian legislation insufficiently ensures international legal standards on the hygienic conditions of prisoners. National legal acts do not entrench the requirement to guarantee the possibility of using hygiene sanitary facilities for prisoners appropriately in order to ensure the respect for their privacy, ${ }^{61}$ as well as the requirement that all chambers should have

56 The representatives of the European Committee for the Prevention of Torture and Inhuman or Degrading Treatment or Punishment in the Reports to the Lithuanian Government on the Visit to Lithuania carried out in 2009 (Report to the Lithuanian Government on the visit to Lithuania carried out by the European Committee for the Prevention of Torture and Inhuman or Degrading Treatment or Punishment (CPT) from 21 to 30 April 2008, CPT/Inf (2009) 22, Strasbourg, 25 June 2009, available at: <http://www.cpt.coe.int/documents/ltu/2009-22-inf-eng.htm>), in 2011 (Report to the Lithuanian Government on the visit to Lithuania carried out by the European Committee for the Prevention of Torture and Inhuman or Degrading Treatment or Punishment (CPT) from 14 to 18 June 2010, CPT/Inf (2011) 17, Strasbourg, 19 May 2011, available at: <http://www.cpt.coe.int/documents/ltu/2011-17-infeng.pdf $>$ ); in 2014 (Report to the Lithuanian Government on the visit to Lithuania carried out by the European Committee for the Prevention of Torture and Inhuman or Degrading Treatment or Punishment (CPT) from 27 November to 4 December 2012, CPT/Inf (2014) 18, Strasbourg, 4 June 2014 available at: <http://www.cpt.coe.int/documents/ltu/2014-18-inf-eng.pdf $>$ ). In this context two cases decided by the European Court of Human Rights could be mentioned: Karalevičius v. Lithuania, App. no. 53254/99, 7 April 2005; Savenkovas v. Lithuania, App. no. 871/02, 18 November 2008.

57 Standard Minimum Rules for The Treatment of Prisoners, 1955, 9(1); Recomendation No. R(2006)2 on the European Prison Rules, 2006, 18.5.

58 The space of a cell must be according to time spent in a cell, a number of other prisoners who live in a cell and the accessibility of sanitary installations ensuring privacy for a person living in a cell (Standart Minimum Rules for The Treatment of Prisoners, 1955, 9, 10, 11, 12; Recomendation No. R(2006)2 on the European Prison Rules, 2006, 19, 19.3).

59 Standard Minimum Rules for The Treatment of Prisoners, 1955, 9(1), 10; Recomendation No. R(2006)2 on the European Prison Rules, 2006, 18.1, 18.3, 18.4, 18.6.

60 Standard Minimum Rules for The Treatment of Prisoners, 1955, 9, 10, 11, 12, 13; Recomendation No. R(2006)2 on the European Prison Rules, 2006, 18.

61 Standard Minimum Rules for The Treatment of Prisoners, 1955, 12, 13; Recomendation No. R(2006)2 on the European Prison Rules, 2006, 19.3, 19.4, 19.7. 
sanitary facilities (toilets) properly encapsulated as is entrenched only partlyin the Lithuanian legislation.$^{62}$ International legal acts establish the requirements that prisoners are provided with suitable for the climate clothing which is not degrading and which meets the person's age. ${ }^{63}$ The Lithuanian legislation entrenches the requirement to provide persons completing their imprisonment sentence in correctional institutions who do not have adequate clothing the clothing corresponding to the climatic conditions. However, this requirement is not prescribed to those persons performing their arrested and punishmed in the open colonies. Additinoally any law includes the specific requirement that the clothing should not humiliate the dignity of the person and should be appropriate in light of his/her age. This situation brings the suffering upon the most vulnerable groups of the prisoners.

The analysis of the Lithuanian legislation showed that the legal requirement of ensuring security compared with the international standards is insufficient. Firstly, there is no direct requirement in the legal acts of Lithuania for thorough selection process of persons to in cells to ensure that they are individuals which can live together in one chamber. ${ }^{64}$ Secondly, there is no obligation of the prison officials for regular security checks of prisoners and for regular security threats to prisoners which is entrenched in the international documents. ${ }^{65}$

According to the international requirements it is necessary to ensure the greater rights protection of imprisoned persons facing with mental or behavioral disorders due to drug and/or alcohol problems. This protection is also related to the provision of appropriate and adequate quality of health care services (especially compared to the analoguos services provided in society). ${ }^{66}$

62 International Covenant on Civil and Political Rights, 1966, 10(1); Standard Minimum Rules for The Treatment of Prisoners, 1955, 12; The United Nations Body of Principles for the Protection of All Persons under Any Form of Detention or Imprisonment. The United Nations General Assembly Resolution No. 43/173 of 9 December, 1988, 1; Basic Principles for the Treatment of Prisoners, 1990, 1; European Convention for the Protection of Human Rights and Fundamental Freedoms, 1950, 3; Recomendation No. R(2006)2 on the European Prison Rules, 2006, 19.3; The European Court of Human Rights case of Peers v. Greece, App. no. 28524/95, §§ 67-68, 74, Reports of Judgments and Decisions 2001-III. For example, in the presented monograph the shortcommings of the regulation of the Minister of Health Ministry of Republic of Lithuania is eluded to in 30 March 2010 No. V-241 "Lithuanian Hygiene Norm HN 76:2010 "On approval of requirements for general health care in the places of imprisonment". These and other shortcommings were identified by the Seimas ombudsmen in their legal acts in 2011 and 2012. These acts are available at: <www.lrski.lt>.

63 Standard Minimum Rules for The Treatment of Prisoners, 1955, 17(1); Recomendation No. R(2006)2 on the European Prison Rules, 2006, 20.1, 20.2.

64 International Covenant on Civil and Political Rights, 1966, 6(1); Universal Declaration of Human Rights, 1948, 3; SMR 9(2), European Convention for the Protection of Human Rights and Fundamental Freedoms, 1950, 2; Recomendation No. R(2006)2 on the European Prison Rules, 2006, 18.6, 18.7; The European Court of Human Rights case of Edwards v. The United Kingdom, App. no. 13071/87, 16 December 1992.

65 Recomendation No. R(2006)2 on the European Prison Rules, 2006, 51.5, 53.51, 53.2.

66 International Convenant on Economic, Social and Cultural rights, 1966, 12(1); Standard Minimum Rules for The Treatment of Prisoners, 1955, 22(1); Principles of Medical Ethics Relevant to the Role of Health Personnel, Particularly Physicians, in the Protection of Prisoners and Detainees against Torture and other Cruel, Inhuman or Degrading Treatment or Punishment, 1982, 1; Recommendation Concerning the Ethical and Organisational Aspects of Health Care in Prison, 1998, 11, 12, 19; Recomendation No. R(2006)2 on the European Prison Rules, 2006, 40. 
In the sphere of legal protection of vulnerable people it is relevant that in Lithuania there are no entrenched obligations that acknowledge prisoners as vulnerable (vulnerability in this context originates not only due to health problems but also includes the risk that a person may commit suicide or injury) are: (1) accommodated in such prison spaces, which are mostly suitable for their monitoring and treatment which is performed by the medical or other significant institutional staff; ${ }^{67}(2)$ constantly monitored by the medical staff and the staff of the prison in the time of their imprisonment and that this monitoring data is recorded; ${ }^{68}$ (3) daily visited (in cases when they are accommodated in special chambers) and monitored by doctors (including their physical and mental health) as often as possible. ${ }^{69}$

So it is stated in the monograph that it is necessary to review the Lithuanian legislation related to the imprisonment activities in order to comply with the requirements of international standards and recommendations because the establisment of legal requirements is a main precondition for ensuring human rights and in order to avoid situations where uncertain or abstract legal regulations become a reason for not recording offences or avoiding legal responsibility for these offences.

The ommission of legislative bodies to correect unconstitutional legal regulation is also a problematic aspect which has to be addressed as a priority because certain legal regulations are recognized as being unconstitutional in the jurisprudence of the Constitutional Court of the Republic of Lithuania. This Court checking the doubts about the non-compliance of legal regulation with the Constitution of the Republic of Lithuania has noted inits several decisions that certain legal regulations are not irreproachable, it is to be corrected..$^{70}$

\subsection{The right to freedom of expression and information}

In section 2.5 title 'The right to freedom of expression and information' of the presented monograph two spheres of legal regulation and practical ensurance of the right to freedom of expression and information are identified and analysed: 1) insufficient ensurance of the protection of a journalist from the disclosure of his/her source of information and 2) the problems of criminal liability for offences of personal honor and dignity. In this article it is relevant to describe the first issue of insufficient ensurance of the protection of a journalist from the disclosure of his/her source of information. ${ }^{71}$

The Constitutional Court of the Republic of Lithuania has noted that the legislator while establishing the powers of the court to deal with the issue of disclosure of the information source has a duty to entrench the legal regulation according to which the court could decide whether the journalist has to disclose his/her source of information only in cases when the other measures of the disclosure of the source of information have already been exhausted. ${ }^{72}$ The legal regulation of Lithuania (the Law on Provision of Information to

67 Standard Minimum Rules for The Treatment of Prisoners, 1955, 22(2), 62; Recomendation No. R(2006)2 on the European Prison Rules, 2006, 12.2, 39, 43.1, 46.2, 47.1, 47.2.

68 R(98)7:58; Recomendation No. R(2006)2 on the European Prison Rules, 2006, 47(2).

69 Standard Minimum Rules for The Treatment of Prisoners, 1955, 25(1), 32(3); Recommendation Concerning the Ethical and Organisational Aspects of Health Care in Prison, 1998, 66; Recomendation No. R(2006)2 on the European Prison Rules, 2006, 43.2.

70 See for example the Constitutional Court of the Republic of Lithuania Ruling of 14 March 2006.

71 It is described according to the presented monograph, 88-90.

72 The Constitutional Court of the Republic of Lithuania Ruling of 23 October 2002. 
the Public, the Code of the Criminal Procedure) does not establish exeptional cases when the court could require the disclose of the secrecy of the information's source of the journalist (that the journalist could disclose his/her souce of information only when all other measures are exhausted). ${ }^{73}$ So the monograph recommends entrenchment of the missing legal provision establishing the case when the secrecy of the information's source of the journalist could be disclosed. It is joyfull after the twelwe years that have passed since the aforementioned ruling of the Constitutional Court of Republic of Lihuania amendment of article 8 of the Law on Provision of Information to the Public was adopted on 14 of July 2014 and this shortcomming of legal regulation was improved. This law now states that 'the producer or disseminator of public information, their participant or a journalist shall have the right to keep the confidentiality of the source of information and not to disclose it, except for the cases where, by a court decision, it is necessary to disclose the source of information for vitally important or otherwise significant public interests, also in order to ensure the protection of persons' constitutional rights and freedoms and the administration of justice'.

\section{CONCLUSIONS}

The position to treat the rule of law as a foundation for the systematic analysis of the ensurance of the guarantees of human rights and respectively the shortcommings of ensuring them is proved by this research. The active role of the state is indispensable while ensuring the implementation of human rights and the state under the rule of law. The identified shortcommings of ensuring separate human rights must not be repeated as we move towards strengthening the ensurance of these rights. In the light of actually not having fully ensured constitutional guarantees of the separate analysed human rights it could be summarized that the principle of rule of law which is enshrined in the preamble of the Constitution of the Republic of Lithuania is also an aspiration, which remains a major challenge for the Lithuanian society.

\section{LITERATURE}

Baltrimas, J., Lankauskas, M. and Šneideris, D., Teisés ị teisinga teisma užtikrinimo problemos (2012) $<$ http://www.teise.org/data/1Teises_i_teisinga_teisma_uztikrinimo_problemos.pdf $>$

Baltrimas, J., Kavoliūnaitè-Ragauskienè, E., Teisès dalyvauti valdant savo šali užtikrinimo problemos (2013) <http://www.teise.org/data/Teise_dalyvauti_valdant_sali.pdf $>$

Beliūnienè, L. et alia (ed.), The Most Relevant Problems of Ensuring of Human Rights in Lithuania 2008-2013: A Legal Research, Researches of the Law Institute of Lithuania (Law Institute of Lithuania 2014)

Bingham, T., The Rule of Law (Penguin 2010)

Birmontienè, T., 'Žmogaus teisių raida ir perspektyvos Lietuvoje' (2000) 5 Jurisprudencija. Teisinès valstybès link 66-72.

Czarnota, A., Krygier, M. and Sadurski, W., (eds) Rethinking the Rule of Law after Communism (Central European University Press 2006).

${ }^{73}$ It should be noted that according to part 3 of article 25 of the Constitution of Republic of Lithuania, "freedom to express convictions, to receive and impart information may not be limited otherwise than by law, if this is necessary to protect the health, honour and dignity, private life, and morals of a human being, or to defend the constitutional order". 
David, C., Fernando, D. H. and Andra, O. M., 'Essentially contested concepts: Debates and applications' (2006) 11/3 Journal of Political Ideologies 211-246.

Jarašiūnas, E., 'Konstitucijos II skirsnio „Žmogus ir valstybe““ komentaras. 18 straipsnis' (1999) 1-2 Teisès probleimos 21-29.

Jarašiūnas, E., 'Žvelgiant į Lietuvos Respublikos 1992 m. Konstituciją platesniame konstitucionalizmo raidos kontekste' (2002) 30/22 Jurisprudencija 47-58.

Krygier, M., 'Rule of Law and the Legal State (Rechtsstaat)' (2013) UNSW Law Research Paper $<$ http://law. bepress.com/unswwps-flrps13/53>

Kūris, E., 'Konstitucija, teisèkūra ir konstitucinè kontrolè: retrospekciniai ir metodologiniai svarstymai' in Lietuvos Respublikos Konstitucijos dvidešimtmetis: patirtis ir iššukiai. Recenzuotu moksliniu straipsniu rinkinys (Vilniaus universiteto Teisès fakulteto Viešosios teisès katedra Lietuvos notarų rūmai 2012)

Küris, E., 'Konstitucinių principu plètojimas konstitucinèje jurisprudencijoje' in Konstituciniu principu plètojimas konstitucineje jurisprudencijoje. Rozwój zasad konstytucyjnych $w$ prawoznawstwie konstytucyjnym (Baltijos kopija 2002)

Miliauskaite, K., Žmogaus teisiu sistema civilizaciju sambūvyje (Lietuvos teisès universitetas 2004)

Peerenboom, R., 'Human Rights and Rule of Law: What's the Relationship?' (2005) 36 Georget J Int Law 809-946.

Waldron, J., 'Is the Rule of Law an Essentially Contested Concept (In Florida)?' (2202) 21/2 Law and Philosophy 137-164.

Žilys, J., 'Kelias į Lietuvos Respublikos Konstituciją: pagrindiniai teisiniai politiniai ženklai' (2013) Nepriklausomybès sasiuviniai <http://www.lrt.lt/naujienos/kultura/26/12807/kelias i lietuvos respublikos_konstitucija_pagrindiniai_teisiniai_politiniai_zenklai> 